\title{
A espacialidade na construção da identidade
}

\section{Spatiality in the construction of identity}

Thiago Duarte Pimentel ${ }^{1}$

Alexandre de Pádua Carrieri ${ }^{2}$

\section{Resumo}

Este artigo tem o objetivo de propor a introdução, tanto conceitual quanto analítica, da dimensão espacial (ou espacialidade) nos estudos sobre identidade no processo organizativo. Para tanto, realizou-se uma retrospectiva analítica sobre o estado da arte do tema identidade no campo dos estudos organizacionais brasileiros, tentando compreender a evolução do tema. Além disso, recorreu-se, de forma indutiva, a algumas das principais contribuições teóricas clássicas (ALBERT; WHETTEN, 1985; BAUMAN, 2005; BERGER; LUCKMANN, 2004; ERIKSON, 1976), visando a uma compreensão mais ampla das origens e da evolução do conceito, bem como, a uma melhor fundamentação da proposta apresentada. A premissa subjacente a este estudo é a de que, apesar dos desdobramentos da assimilação e aplicação do tema identidade nos EO's brasileiros, os pesquisadores têm se limitado, com raras exceções, a reproduzir e a aplicar o conceito "clássico" de identidade proposto por Albert e Whetten (1985), sem, contudo, preocupar-se em criticar, desenvolver, ampliar e inovar essa base teórica. Como movimento inicial e parcial para superar tal limitação, propõe-se a incorporação de uma nova categoria analítica e conceitual, a espacialidade, visando desenvolver conceitualmente o campo e, ao mesmo tempo, fornecer um novo elemento de análise empírica. Obviamente, sugere-se que a proposição aqui defendida seja validada pelo conjunto de pesquisadores deste campo temático, por meio de pesquisas qualitativas e quantitativas.

Palavras-chave: identidade; espacialidade; modelo teórico.

\begin{abstract}
This paper aims to propose an introduction of the spatiality dimension on the concept of identity in two ways: as a conceptual as well an analytical category for the study of identity in the organizing process. In so doing, we have conducted a critical overview of the literature concerning Identity in the field of Brazilian Organizational Studies. We have attempted to comprehend the evolution of the theme. Moreover, we have resorted, in a inductive way, to some classic theoretical foundations (ALBERT; WHETTEN, 1985; BAUMAN, 2005; BERGER; LUCKMANN, 2004; ERIKSON, 1976) aiming to better understand the origins and evolution of the concept of identity, in addition to adding more strength to the theoretical proposition. Despite the apparent evolution of the theme in Brazilian EO's, with assimilation and replication of the most internationally important ideas in the Brazilian context, this study is based on the assumption to which the researchers have limited themselves, with few exceptions, to reproduce the classical concept of identity proposed by Albert \& Whetten (1985), without, however, concerning themselves with developing and expanding the concept. Despite this restriction, we have proposed here a new analytical and conceptual category: spatiality. This could be incorporated into the framework of the theme of identity, in an effort to develop it and, simultaneously, supply a new element for empirical investigation. Obviously, this proposition is merely a starting point, which must be validated by the researchers in the field, using qualitative and quantitative methods.
\end{abstract}

Key words: identity; spatiality; theoretical model.

1 Doutorando em Administração pela Universidade Federal de Lavras (UFLA). Professor assistente 1 do departamento de Turismo da Universidade Federal de Juiz de Fora (UFJF). Endereço: Campus Universitário, Rua José Lourenço Kelmer, s/n - São Pedro - Juiz de Fora/MG, CEP 36036-330. Email: Thiago.pimentel@uff.edu.br

2 Professor Associado CEPEAD/CAD/FACE/UFMG, Coordenador do Núcleo de Estudos Organizacionais e Sociedade (NEOS). Endereço: Av. Antônio Carlos 6627 Sala 4070 e 4071, Pampulha, Belo Horizonte, MG, CEP 31270-901. Email: alexandre@cepead.face.ufmg.br 


\section{Problematizando o atual l'etat d'art do tema identidade nos EO's (brasileiros)}

Este artigo tem o objetivo de propor a introdução, tanto conceitual quanto analítica, da dimensão espacial (ou espacialidade) nos estudos sobre identidade no processo organizativo das organizações.

Vários têm sido os estudos sobre o tema identidade. Desde a filosofia, passando pela religião, história, psicologia e pelas ciências sociais, esse tema percorreu um longo e milenar caminho até chegar à sua aplicação no campo dos estudos organizacionais. Nesse campo, os estudos que começaram a surgir, esporádica e isoladamente, a partir da segunda metade do século XX foram intensificados nas décadas ulteriores, sobretudo, a partir do clássico artigo de Albert e Whetten, em 1985. O tema foi despertando o interesse da comunidade acadêmica do campo organizacional, que buscava, na maioria das vezes, compreender por meio dele as formas de diferenciação organizacional e o desenvolvimento de vínculos psicológicos dos trabalhadores com a organização (HATCH; SCHULTZ, 2004).

Inicialmente, os estudos sobre identidade desenvolveram-se gradativamente a partir da perspectiva da observação individual e interna, passando pela perspectiva da observação externa, até se chegar a abordagens que tratam da integração da perspectiva individual com o reconhecimento da influência social (HARDY; LAWRENCE; GRANT, 2005; HATCH; SCHULTZ, 2004). Outra questão observada como importante elemento de análise da identidade foi a multiplicidade de níveis de análise: individual, grupal, organizacional ou societal.

Com o trabalho de Albert e Whetten (1985), outras três categorias foram acrescentadas ao estudo de identidade: centralidade, distintividade e continuidade temporal. Essas categorias foram chamadas de "conceituais" por Wood Júnior e Caldas (2006), enquanto o nível de observação (individual ou coletivo) e as perspectivas de estudo do tema (interna ou externa) foram denominadas "ontológicas". Em última instância, os estudos sobre o tema têm girado, basicamente, em torno dessas cinco categorias: duas ontológicas - nível de análise e unidade de observação - e três conceituais - centralidade, distintividade e temporalidade -, que têm sido combinadas de diversas formas quando se pretende estudar o objeto proposto (WOOD JÚNIOR; CALDAS, 2006).

Vale ressaltar que tal proposição sobre o estado da arte do tema identidade sintetizada pelo quadro de Wood Júnior e Caldas (2006) não leva em consideração (ou toma por implícitos) os processos de construção identitária: a) por identificação, que remete ao alinhamento do universo simbólico do plano individual em relação ao social; e b) por socialização, que se refere ao processo de transmissão de regras e normas de condutas tidas como socialmente aceitas por um dado grupo social a um indivíduo (BERGER; LUCKMANN, 2004).

Apesar da relevância de outros conceitos para a ampliação do potencial explicativo das teorias de identidade relacionadas ao processo organizativo - e passados 25 anos desde o trabalho de Albert e Whetten (1985) -, poucos têm sido os estudos que buscaram explorar novas categorias de análise para o desenvolvimento do tema no Brasil. Um exemplo é a dimensão espaço, físico e simbólico, que tem sido esporádica e marginalmente trabalhada por poucos autores. É o caso de Fischer (1994), que evidencia como o espaço organizacional está permeado de significados que permitem e auxiliam a construção de uma identidade organizacional, ou melhor, do e no processo organizativo. Carrieri e Pereira (2003), por sua vez, observam empiricamente como a imagem de um espaço turístico está associada ao espaço físico e simbólico, enquanto Carrieri (2005) evidenciou como a transformação da identidade institucional da Feira de Arte, Artesanato e Produtores de Variedades da avenida Afonso Pena, em Belo Horizonte, estava associada ao espaço físico e à representação desse espaço por parte dos seus frequentadores: trabalhadores, consumidores e visitantes

Assume-se aqui que este estudo parte de duas premissas: a primeira é a de que há uma estagnação do tema identidade no campo dos estudos organizacionais brasileiros, que tendem a reproduzir um determinado padrão, aceito e legitimado socialmente pelos pesquisadores tupiniquins, a respeito do conceito de identidade, como se este já estivesse "acabado" ou completo. Assim, devido à falta de crítica e à passiva assimilação de tal conceito, na maioria das vezes, os pesquisadores tenderiam a se limitar a produzir reclassificações e compilações das perspectivas adotadas nos estudos já realizados, inibindo o desenvolvimento teórico de tal conceito nos EO's brasileiros. Longe de desmerecer a sistematização dos estudos de qualquer campo (pois, reconhecemos sua 
necessidade, inclusive, para se alcançar um novo patamar), o que se advoga aqui é a necessidade de transcender tal processo, acrescentando elementos que ampliem a compreensão da realidade. A segunda premissa subjacente a este estudo é a de que uma importante categoria tem sido sistematicamente omitida da análise da identidade nos EO’s brasileiros: a dimensão espacial.

Considerando-se que a) há uma relação dialética entre as categorias espaço e identidade, partindo do princípio de que o espaço opera como meio de produção de identificação dos indivíduos com o seu mundo social; b) que é o espaço que medeia as relações sociais, e com isso fornece as bases para a construção e (re)construção de significados subjetivamente compartilhados sobre si, sobre os outros e sobre a própria dimensão da realidade, permitindo aos indivíduos relacionarem-se consigo mesmos, com os outros e com o mundo natural e social (BERGER; LUCKMANN, 2004), propõe-se aqui a adoção desse elemento como uma categoria conceitual e analítica do tema identidade.

Grande parte das contribuições angariadas pela ciência da administração advém do estudo sistemático da manipulação do tempo e do espaço. Isso pode ser constatado, por exemplo, pelo desenvolvimento de técnicas de apressamento da produção por Taylor (1995), já no início do século XX, e pela revolução no uso do espaço organizacional proposto pela linha de montagem (FORD, 1954) e suas contínuas reavaliações ulteriores, como a realizada pelo toyotismo (CORREA; GIANESI, 1996; WOOD JÚNIOR, 1992). A despeito disso, o estudo do espaço parece ter sido sistematicamente omitido da agenda dos EO's brasileiros (ALCADIPANI; ALMEIDA, 2000; GOMES-da-SILVA; WETZEL, 2006; PIMENTEL, CARRIERI; LEITE-da-SILVA, 2007).

O espaço, como mediador das relações sociais, pode ser visto como uma forma de controle social (FOUCALT, 1989) e de domínio do homem sobre a natureza (LEFBVRE, 1991), segundo a qual o seu uso e sua forma representariam uma ordem simbólica subjacente, histórica e socioculturalmente construída (BERGER; LUCKMANN, 2004). O conhecimento dessa ordem simbólica, por meio de suas manifestações materiais e imateriais, poderia esclarecer as relações que os atores sociais estabelecem com o espaço e entre si mesmos.

A principal contribuição que se pretende dar com este artigo é preencher uma lacuna no quadro de estudo da identidade sistematizado e proposto por Wood Júnior e Caldas (2006) - que pode ser considerado representativo do état d'art do tema, sobretudo, no Brasil -, propondo-se, então, um avanço no seu desenvolvimento conceitual analítico, a partir da incorporação da dimensão espacial. Essa incorporação parece ser promissora, pois, como alguns estudos recentes têm constatado, a identidade no processo organizativo (social e pessoal) está relacionada com a dinâmica dos grupos sociais e sua relação com a ocupação e manipulação de um dado espaço (CARRIERI, 2005; GOMES-da-SILVA; WETZEL, 2006; PIMENTEL, CARRIERI; LEITE-da-SILVA, 2007).

Este artigo está organizado em quatro seções além desta introdução, onde são apresentadas as razões que motivaram a realização deste estudo, a saber: o relativo estágio de estagnação conceitual do tema identidade no campo dos estudos organizacionais no Brasil. Na primeira seção, são discutidos alguns dos principais conceitos de identidade, desde sua origem no campo da filosofia, passando pelo seu desenvolvimento no campo das ciências sociais. A segunda seção discute a identidade no campo dos estudos organizacionais, focalizando a identidade organizacional e a identidade no ambiente de trabalho. Na terceira seção, é proposta uma nova categoria conceitual e analítica para o estudo do tema. Por fim, são tecidas algumas considerações parciais, às quais este estudo permitiu chegar.

\section{Antecedentes do estudo de identidade}

Ésther (2007) considera que a palavra identidade é usada no cotidiano para responder à pergunta "Quem eu sou?". Segundo o autor, a resposta é a descrição de uma personagem cuja biografia aparece numa narrativa. Tal narrativa pode ser realizada tanto do ponto de vista individual quanto coletivo. No entanto, apesar de ser cotidiana e comumente utilizada, a identidade possui uma raiz remota e longínqua. Alguns autores, como 
Caldas e Wood Júnior (1997), apontam que a questão da identidade tem as raízes fundadas no pensamento clássico, sendo um tema tão antigo quanto a própria lógica, a álgebra e a filosofia.

No âmbito da lógica, por exemplo, a questão de identidade seria, per se, um dos axiomas da matéria, uma vez que seria tomada como a igualdade entre duas expressões representadas pelo mesmo número. Isto é, uma determinada entidade seria idêntica a si mesma sempre que para qualquer " $x$ " o resultado fosse igual a " $x$ ". Segundo Caldas e Wood Júnior (1997), teria sido no campo da filosofia que tais ideias foram alvo de um impulso reflexivo intelectual, o que estimulou a sua propagação e assimilação tanto em seu uso pela cultura popular, quanto na reflexão filosófica e intelectual dos séculos ulteriores.

Segundo Machado (2001), foi o filósofo Parmênides de Eléia $(540$ - 450 a.C.) que definiu o princípio da identidade ao anunciar que $o$ que é, é e que uma coisa idêntica seria aquela em que uma coisa é igual a si mesma. Nesse sentido, a ideia de identidade fundar-se-ia no princípio tautológico, em que uma coisa só poderia ter existência e significado em si e por si mesma, o que sugeriria um radicalismo na autodefinição das entidades - coisas e seres humanos. Nessa acepção de identidade, os atributos de cada coisa (ou indivíduo) seriam tão exclusivos que só se poderia pensar neles a partir deles mesmos, e, além disso, estaria a falta (ou incapacidade) de percepção e de tomada de consciência das coisas. Assim, o princípio da identidade estaria baseado nos seguintes atributos: unicidade, continuidade, imobilidade (estabilidade), infinitude, eternidade, homogeneidade (no sentido de não variação) e indivisibilidade (MACHADO, 2001), que seriam responsáveis por conferir à identidade, justamente, essa característica tautológica e autodefinida.

Entretanto, foi com o filósofo Heráclito de Éfeso (540 - 480 a.C.), maior opositor intelectual de Parmênides, que o princípio da identidade passaria a ser universalmente reconhecido e referenciado (CALDAS; WOOD JÚNIOR, 1997). Ao sustentar o axioma de que a essência das coisas consistiria na sua própria mudança e de que a base de tudo era a luta dos contrários, a partir da qual a sua síntese seria crucial para se interpretar a natureza e relacionar-se com ela, Heráclito (1980) estabelece uma concepção "embrionária" da filosofia dialética. Uma consequência disso foi a ruptura com a premissa tautológica de autodefinição da identidade proposta por Parmênides.

Mais recentemente, na filosofia dos séculos XIX e XX, passou-se a discutir de modo aprofundado a questão da identidade seguindo essa mesma linha de análise. Heidegger (1979) afirma que o princípio da identidade é abstrato e só se manifesta na singularidade. Esta, por sua vez, poderia ser vista pelo homem (e suas particularidades) em sua relação/contraposição à coletividade (ou aos outros). Segundo esse autor, o termo identidade vem do latim (idem) e do grego (tò autó), significando o mesmo. A filosofia existencialista de Heidegger (1979), além de retomar a lógica dialética heraclitiana, abre portas para a introdução da relação indivíduo e espaço - mais especificamente identidade e espaço -, ao considerar a existência como a possibilidade de projeto, que se manifesta sempre a partir da historicidade do ser-aí (do ser no mundo). A ontologia do ser é tomada, então, como um elemento central e fundador da própria identidade.

Da negação da possibilidade no real de algo a que corresponda um conceito de identidade à sua afirmação são muito comuns as seguintes atribuições de sentido a identidade :

A característica daquilo que é [...] [por exemplo] "A identidade da Batalha de Koniggraetz e da batalha de Sadowa”. [...] Característica de um indivíduo ou de um ser assimilável sob este ponto de vista a um indivíduo acerca de quem se diz que é idêntico, ou que é o "mesmo" nos diferentes momentos da sua existência: "A identidade do eu". "O reconhecimento da identidade de um indivíduo condenado... será feito pelo tribunal". (Code d'inst. Criminelle, art. 518) [...] Estes dois primeiros sentidos são designados indistintamente, de ordinários, pelo nome de identidade numérica. Para [este último] sentido diz-se também identidade pessoal, identidade jurídica. (LALANDE, 1985, p.505-506 - itálico nosso)

Lalande acrescenta que há também:

Característica de dois objetos de pensamento, distintos no tempo e no espaço, mas que apresentariam as mesmas qualidades. Este sentido é designado comumente sob o nome de identidade qualitativa. (LALANDE, 1985 , p.506 - itálico no original) 
Com efeito, se a identidade entre um objeto e outro é absoluta, na verdade não há dois objetos, mas apenas um. Ademais, mesmo que tal quimera fosse possível, não poderia ser acedida por um ser humano, dado que tal aquiescência está condicionada ao pleno conhecimento do objetivo dos entes identificados, ao passo que o conhecimento humano é sempre parcial, aproximativo e fundado em representações.

Por essa razão, é considerado de extrema importância o trabalho de Rey (2005), para quem existe uma realidade social, que, contudo, é impossível de ser acessada de forma total e direta. O conhecimento do real seria sempre parcial e limitado, devido às próprias práticas de intervenção do pesquisador. Não existiria uma concepção exclusiva da realidade, como realidade última, total ou absoluta. Seria sempre possível aprofundarse no entendimento dos fatos, tendo em conta a realidade como algo a ser constantemente interpretado. A partir disso, Rey (2005) apresenta o conceito de zonas de sentido, que seriam espaços de inteligibilidade, gerados pelas pesquisas científicas, capazes de abrir possibilidades de aprofundamento em um campo de construção teórica. Esse conceito pressupõe a função do conhecimento científico como:

[...] gerar campos de inteligibilidade que possibilitem tanto o surgimento de novas zonas de ação sobre a realidade, como de novos caminhos de trânsito dentro dela através de nossas representações teóricas. O conhecimento legitima-se na sua continuidade e na sua capacidade de gerar novas zonas de inteligibilidade acerca do que é estudado e de articular essas zonas em modelos cada vez mais úteis para a produção de novos conhecimentos. (REY, 2005, p.6)

Esse é o campo dos estudos de identidade, não só nas ciências sociais como também nas organizações. A partir dessas concepções teóricas desenvolvidas pela e na filosofia é que outros estudos no campo das ciências sociais e, em especial, no campo da psicologia começaram a ser desenvolvidos, tentando verificar como aqueles conceitos teleológicos poderiam ser utilizados e verificados na prática cotidiana dos atores sociais.

Com o desenvolvimento dos estudos de identidade na perspectiva da filosofia, o tema identidade foi espalhando-se para outros campos do saber, inicialmente, nas áreas de humanidades, estando hoje virtualmente integrado na pluralidade das áreas do conhecimento. Mauss (1938), no seu ensaio Uma categoria do espírito humano: a noção de pessoa, a noção do 'eu'”, considera que a categoria identidade nas ciências sociais tem uma longa história, cujo começo remonta à Antiguidade clássica.

As condições para o estabelecimento de tal categoria nas ciências da sociedade, nascidas nos séculos XIX e XX, começam a aparecer quando a noção de pessoa transmutou-se na noção de pessoa romana, como um fato fundamental do direito. Cabe observar que a noção de pessoa tem origem no teatro de máscaras grego e sua importância reside no fato de ter "[sintetizado] o antagonismo vivido pelos gregos, nos processos de identificação, seja na 'representação do idêntico, seja na representação construída por processos de reconhecimento, nas relações com o outro"'(LOPES, 2002, p.9).

No período medieval, quando o poder político e o poder religioso estavam casados (configurando o que se chamou de Cristandade), afirmou-se a noção de pessoa humana. Esta, embora dual (por ser feita de corpo e alma, consciência e ação), seria indivisível, una e permanente. Sua essência residia, não com o mundo fugaz, mas em sua relação com o eterno - sobretudo, numa relação moral - fazendo a identidade do homem corresponder à identidade de um Deus simultaneamente uno e trino, e, como Deus encarnado na condição humana, de uma dupla natureza, humana e divina, em Cristo, sem, no entanto, deixar de ser a mesma pessoa, eterna, todo-poderosa, onisciente e onipresente (MAUSS, 1938).

A história propriamente dita teria começado na modernidade, com a emergência de dois conceitos: a pessoa, equivalendo ao eu, e a consciência, reduto último da liberdade e da individualidade de todos os homens. Nesse processo, sem que se tenha perdido a conotação moral da noção de pessoa, é reforçada a noção de pessoa psicológica. A emergência das ciências humanas - sobretudo, da antropologia e psicologia - teria trazido consigo três registros da consciência humana: a) a figura do ego, a identidade da consciência de si mesma; b) a consciência da pessoa moral; e c) o sujeito cognoscente, sujeito conhecedor.

No campo da antropologia,em particular no da antropologia cultural, Hall (2005) destaca a evolução do conceito de identidade consoante à evolução da própria sociedade, distinguindo três tipos de concepções sobre 
identidade: a) identidade do sujeito no Iluminismo; b) identidade do sujeito sociológico; e c) identidade do sujeito pós-moderno. Segundo Hall (2005), a identidade do sujeito no Iluminismo seria aquela em que predominaria a concepção de um sujeito uno, centrado, com características rígidas e inflexíveis. Já a identidade do sujeito sociológico seria aquela marcada pela consciência de que aquele núcleo interior do sujeito do Iluminismo não era autônomo nem autossuficiente, sendo a sua formação baseada na relação com os outros. Nessa segunda concepção, o sujeito ainda tem uma essência, ou núcleo, interior formado com base na interação com os outros. Por fim, a concepção de identidade do sujeito pós-moderno seria aquela em que

[...] as identidades que compunham as paisagens "lá fora" e que asseguravam nossa conformidade subjetiva com as "necessidades" objetivas da cultura, estão entrando em colapso, como resultado de mudanças estruturais e institucionais. O próprio processo de identificação, através do qual nos projetamos em nossas identidades culturais, tornou-se mais provisório, variável e problemático. (HALL, 2005, p.12)

Hall (2003) identifica cinco grandes avanços nas teorias sociais e nas ciências humanas que teriam provocado um deslocamento na concepção da identidade, apontando para um possível processo de fragmentação. $\mathrm{O}$ primeiro seria a releitura da teoria marxista na década de 1960. Essa nova interpretação, segundo o autor, teria defendido que Marx colocava as relações sociais, e não o indivíduo, como ponto central de sua teoria.

O segundo avanço seria a noção de inconsciente elaborada por Freud. De acordo com o pai da psicanálise, a identidade, a sexualidade e os desejos do ser humano são formados a partir de processos psíquicos e simbólicos do inconsciente. Como este funciona de uma forma diferente da razão consciente humana, pode-se afirmar que a teoria de Freud questiona o conceito de identidade racional, fixa e unificada. Ao invés de se tratar do tema da identidade, dever-se-ia falar de identificação e vê-la como um processo em andamento.

Dentre essas diversas áreas que incorporaram a discussão sobre a questão da identidade, o campo da psicologia e o da psicanálise têm grande destaque, uma vez que instigaram e possibilitaram um salto qualitativo e operacional no seu desenvolvimento durante o século XX.

Foi no campo da psicologia que a identidade ganhou forte impulso com os estudos de Erikson - um importante psicanalista a trabalhar na área de psicologia do desenvolvimento que desenvolveu sobremaneira o conceito de identidade (McKINNEY; FITZGERALD; STROMMEN, 1986) -, para quem a identidade pessoal estaria ligada à noção de continuidade histórica, sendo entendida como "um sentimento subjetivo de uma envigorante uniformidade e continuidade" (ERIKSON, 1976, p.17, itálico no original).

O terceiro marco teórico (além da pré-história e da história) do descentramento identitário estaria relacionado com o trabalho do linguista Saussure. Para ele, os significados das palavras não são fixos, mas sim inerentemente instáveis. Procura-se um fechamento (identidade) para o significado, mas este é constantemente perturbado pela diferença. Assim, o que se argumenta é que o individuo nunca tem o controle total dos significados, o que inclui o significado de sua identidade.

O quarto avanço teórico assinalado por Hall (2003) estaria presente no trabalho de Foucault. Para ele, Foucault (1989) demonstrou que, a partir do desenvolvimento de novas instituições coletivas, o poder disciplinar tornase cada vez mais refinado e individualizado. Observa-se que, quanto mais coletiva e organizada a natureza das instituições da modernidade tardia, maior o isolamento, a vigilância e a individualização do sujeito.

O último descentramento apontado seria o movimento feminista, tanto como uma crítica teórica quanto como um movimento social. Como movimento, o feminismo apelaria para uma identidade sustentadora: ser mulher. Isso foi parte do surgimento de vários outros movimentos sociais baseados na política de identidade. Além disso, como crítica, o feminismo politizou a subjetividade, a identidade, o processo de identificação e a forma como as pessoas são produzidas como sujeitos generificados (HALL, 2005).

Todas essas ideias e movimentos listados por Hall (2005) tiveram grande impacto sobre o pensamento e a forma de concepção da identidade no contexto atual. A questão do estudo sobre identidade baseia-se, então, fundamentalmente, nas visões essencialistas e não-essencialistas, ou seja, na concepção da identidade 
individual como coerente e permanente ou como um processo fragmentado e instável (WOODWARD, 2000). A compreensão da identidade, de acordo com a perspectiva não-essencialista, perpassa o entendimento de processos de representação, socialização, identificação e de diferenciação.

Tendo como base tais noções, as ciências humanas desenvolveram o conceito de identidade. Normalmente, cabe ressaltar aqui, ao identificar, o que era feito na verdade por meio do exercício de poder (ALCADIPANI, 2005). Ratificando tal proposição, Lopes (2002) traz à baila uma observação sua assaz importante, sugerindo sutilmente que, ao tratarem de identidades, psicólogos e antropólogos se dirigiram a grupos humanos ditos periféricos: índios, gays, negros, trabalhadores rurais e urbanos, movimentos sociais etc. Dado que o lugar de pesquisador, intelectual e/ou acadêmico configura também determinado status nas sociedades modernas, ao fazê-lo, realizaram uma estratégia de poder.

Assim, a palavra, o princípio, a noção e o conceito de identidade costumam ser, simultaneamente, objetos e instrumentos de lutas simbólicas, na acepção com que Bourdieu (2002) toma essa expressão, a saber: lutas de e por poder simbólico. Nela, as "palavras mágicas" (estrutura, identidade, poder, classe etc.) entram em disputas e compete-se por seu sentido legítimo, bem como pela autoridade de definir tal sentido, quer dizer, o controle das condições de legitimação. Há, portanto, uma dupla realidade: da palavra, princípio, conceito e representação como objeto de luta; de seu uso como instrumento dessas mesmas lutas.

Corroborando essa perspectiva de identidade como fruto das relações de poder, Bauman (2005) considera que a noção de identidade constrói uma interpretação em que tal identidade seria vista como uma invenção social da classe que tem o poder, relacionada com um determinado espaço físico e simbólico, como uma noção de pertencimento a um lugar estabelecido ou imposto por algum grupo a alguém. Essa noção - segundo ele, estreitamente relacionada à dimensão espacial - é fruto de um dado contexto sócio-histórico e cultural, que inicialmente estava associada à formação dos Estados nacionais. Aqui, fica explícita a relação entre espaço e identidade, sendo esta um produto da era moderna de formação dos Estados nacionais. De particular importância é a análise de Foucault sobre o papel do poder na produção de subjetividades e de identidades (ALCADIPANI, 2005), que fornecerá as bases para a adoção do espaço como categoria potencialmente útil na análise da produção de identidade, pois é no e pelo espaço que se dão as lutas pelo poder (simbólico).

Porém, toda essa dinâmica do exercício do poder e, consequentemente, da formação de identidades, inscreve-se num processo mais amplo de construção e apreensão da realidade, que, como bem explicam Berger e Luckmann (2004, p.228), está fundamentalmente ancorado nos processos de institucionalização.

Os processos sociais implicados na formação e conservação da identidade são determinados pela estrutura social. Inversamente, as identidades produzidas pela interação do organismo, da consciência individual e da estrutura social reagem sobre a estrutura social dada, mantendo-a, modificando-a ou mesmo remodelando-a. As sociedades têm histórias no curso das quais emergem particulares identidades. Estas histórias, porém, são feitas por homens com identidades específicas. Se tivermos em mente essa dialética, podemos evitar a noção equivocada de "identidades coletivas" sem precisar recorrer à unicidade, sub specie aeternitatis, da existência individual.

Essa perspectiva construtivista do papel da interação social é fundamentalmente marcada pelo trabalho de Goffman (1975), que explicitamente discute a identidade a partir da interação e do contraste derivado de tal interação, onde fica explícito o seu caráter social, a começar pela identidade pessoal:

Ao usar o termo "identidade pessoal", pretendo referir-me somente às duas primeiras ideias - marcas positivas ou apoio de identidade e a combinação única de itens da história de vida que são incorporados ao indivíduo com o auxílio desses apoios para a sua identidade. A identidade pessoal, então, está relacionada com a pressuposição de que ele pode ser diferenciado de todos os outros e que, em torno desses meios de diferenciação, podem-se apegar e entrelaçar, como açúcar cristalizado, criando uma história contínua e única de fatos sociais que se torna, então, a substância pegajosa à qual vêm se agregar outros fatos biográficos. (GOFFMAN, 1975, p.67) 
A identidade social, por sua vez, seria aquela decorrente da inserção do indivíduo em algum grupo diferenciado. Tanto a identidade social quanto a pessoal, afirma Goffman (1975), decorrem dos interesses e pontos de vista que as pessoas com as quais um indivíduo interage mantêm com relação a ele. O notável desse autor é que, além dessas identidades, que são frutos das múltiplas inserções sociais do indivíduo e de processos de identificação, há um reconhecimento do que Erickson denominou "identidade do eu" ou "identidade experimentada" (felt identity):

[...] a identidade do "eu" é, sobretudo, uma questão subjetiva e reflexiva que deve necessariamente ser experimentada pelo indivíduo cuja identidade está em jogo. (GOFFMAN, 1975, p.116)

Dessa forma, a identidade ancora-se numa perspectiva relacional e comparativa, na qual as pessoas tenderiam a se classificar e a classificar os outros de acordo com várias categorias e papéis sociais já criados pelo grupo social (por exemplo: "bonzinho", "vilão", "mundano"). As identidades sociais seriam formadas também por direitos normativos, obrigações e sanções, que acabam por constituir esses papéis ao serem assumidos. Assim, a identidade social é mais do que a concepção individual de si mesmo, pois esta depende do reconhecimento e legitimação dos outros que compõem a realidade social do sujeito (BERGER; LUCKMANN, 2004).

A partir das contribuições dos estudos da psicologia e da sociologia podem ser identificados dois processos complementares de construção de identidade: de um lado, as correntes da psicologia contribuem com a noção de identificação, como um processo eminentemente subjetivo, que se origina do sujeito em relação ao Outro (ou Outros) que lhe são significativos (ERIKSON, 1976); de outro, as diferentes correntes das ciências sociais identificam a existência de um processo denominado "socialização", que faria justamente o caminho inverso da identificação - ou seja, ele seria constituído pela transmissão de determinados tipos de comportamentos, valores e normas socialmente aceitas e tidas como corretas por um determinado grupo social para um indivíduo ou um grupo (BERGER; LUCKMANN, 2004).

Em suma, enquanto na psicologia a identidade é vista a partir de uma dimensão de autopercepção, fortemente centrada no indivíduo como objeto focal, na sociologia ela é comumente vista a partir de uma dimensão de observação externa ao indivíduo, ou seja, a identidade de alguém ou de algum objeto é dada pela maneira como os outros o veem. Além disso, nessa perspectiva geralmente o objeto focal desloca-se do individuo para o grupo, ou seja, é a identidade coletiva que entra em cena. Longe de se anularem, essas perspectivas se complementam ao explorarem facetas diferentes de um mesmo fenômeno que se desenvolve em vários níveis diferentes.

\section{Identidade organizacional e identidade no trabalho}

No campo dos estudos organizacionais, a dupla possibilidade de estudos do tema identidade aplicada ao contexto organizacional é oriunda das tradições, de um lado, da psicologia e, de outro, da sociologia, que, basicamente se mostram de duas formas distintas:

a) uma mais preocupada com o sujeito e, por isso, associada à vertente psicológica, representada pelos estudos de identidade (no ambiente de) trabalho; e

b) outra centrada nas relações sociais dos sujeitos, na conformação de um padrão de comportamento grupal e na transposição de elementos individuais para o coletivo, sendo, portanto, associada à vertente sociológica e representada pelos estudos de identidade organizacional.

Bauer e Mesquita (2007) observam na literatura internacional que os trabalhos sobre identidade seguem diversas linhas epistemológicas e que abordam tanto o nível coletivo, da identidade corporativa (ou imagem organizacional), como o caráter mais subjetivista, da identidade social e identificação. Já na literatura nacional, predominam os estudos sobre identidade na organização, em vez da identidade da organização. Nesse sentido, 
para os autores, a produção brasileira sobre o tema tem se voltado mais para a análise da identidade dos indivíduos inseridos nas estruturas organizacionais.

Apesar da distinção clara entre as concepções, deve ser ressaltado que, ao se tratar de identidade organizacional, acaba-se mencionando aspectos da identidade pessoal, da identidade no trabalho e da identidade social, o que demonstra certa complementaridade entre essesfenômenos (MACHADO; KOPITTKE, 2002). Haveria uma ligação possível entre as diversas abordagens, mesmo de opções paradigmáticas diferentes, pois qualquer estudo sobre identidade se fundamenta a partir do comportamento de indivíduos ou de grupos, ou seja, do comportamento humano nas organizações (BAUER; MESQUITA, 2007).

No âmbito dos estudos sobre identidade no trabalho, Sainsaulieu (1997) dedicou décadas de estudo à questão. Já nos anos 1960 e início da década de 1970, partindo do fato de que o ambiente de trabalho é um ambiente de socialização e de que a mudança de representação pode conduzir a uma mudança na percepção que os indivíduos têm de si mesmos e à evolução das identidades coletivas, Sainsaulieu (1997) identificou em mais de 50 ateliers e serviços administrativos quatro modelos de normas e valores, ou como o próprio autor considera, quatro modos de identidades coletivas:

a) modo de fusão - pelo qual o coletivo é valorizado como refúgio e proteção contra as clivagens, predomina no trabalho sem qualificação profissional, simplificado e repetitivo ao extremo;

b) modo de negociação - nele se observa a riqueza afetiva e cognitiva das relações interpessoais, a aceitação do debate produtivo entre maioria e minoria e a importância do tipo de vida democrática, sendo verificado no trabalho de ourives profissionais, de empregados e agentes técnicos que exercem um determinado métier;

c) modo de afinidade - identificado nas situações de mobilidade socioprofissional prolongadas nas empresas (ou onde houvesse a promoção interna em função do crescimento pessoal e do número de quadros de agentes e técnicos), estando associado a autodidatas; e

d) modo de retirada - caracterizado por um jogo muito fraco de relações interpessoais e coletivas, no qual as pessoas mantêm relações superficiais no trabalho, o grupo é recusado e a liderança também. $O$ trabalho não é um valor nessa estrutura de relações, mas antes uma necessidade.

Na década de 1990, Sainsaulieu (1997) aprofunda seus estudos identificando sete tipos diferentes de identidade no trabalho, a partir das polaridades entre integração (por estatuto, por classe, par la Maison e pela empresa) e diferenciação social (pelo estrato profissional, pelo métier, por projeto), gerando basicamente dois grandes posicionamentos: um mais defensivo (estável e estatutário) e outro mais ofensivo (adaptativo e dinâmico), como resultado de pressões e mudanças internas e externas ao contexto organizacional.

Já na área dos estudos sobre identidade organizacional, o estudo sobre a identidade passou a conquistar espaço a partir do artigo seminal de Albert e Whetten (1985), o qual transportou as principais formulações de Erikson (1976) e de outros estudiosos da psicologia a respeito do conceito de identidade do nível individual para o nível organizacional de análise, estabelecendo três critérios clássicos para a sua observação: a) centralidade - o que é a essência da organização; b) distintividade - o que a diferencia das demais de um mesmo grupo ou com características semelhantes; e c) continuidade temporal - que se referiria à manutenção e estabilidade de determinadas características ao longo do tempo.

Almeida (2005) pondera que alguns estudos isolados e baseados em perspectivas diversas sobre identidade, imagem e reputação organizacional já vinham sendo desenvolvidos desde a década de 1950. Entretanto, segundo Almeida e Bertucci (2007), somente a partir da década de 1990 - sobretudo, em temas como valor da marca, na área de marketing; imagem institucional e responsabilidade corporativa, na área de sociologia; e estratégias de comunicação, nas áreas de comunicação - é que esses estudos ganharam ênfase, sugerindo a relevância do trabalho de Albert e Whetten (1985) para o desenvolvimento do campo. 
Especificamente no campo dos estudos organizacionais, Wood Júnior e Caldas (1995) buscaram sistematizar um modelo analítico do conceito de identidade e de seus processos de mudança, estabelecendo um quadro analógico entre identidade individual e identidade organizacional. Para esses autores, haveria diversos níveis possíveis de definição de identidade e suas possíveis correspondências no âmbito tanto do objeto focal quanto das dimensões de análise. Além disso, o conceito variaria de acordo com o "objeto focal" analisado, ou seja, de acordo com o nível de análise - individual, grupal, organizacional, social etc. Também se modificaria segundo sua forma de observação interna (como um dado indivíduo ou grupo se define, com base no que ele acha que é) ou externa (como é definido pelos outros ou com base no que os outros pensam dele).

Uma contribuição deste estudo de Wood Júnior e Caldas (1995) é a proposição do uso da metáfora-raiz como estrutura auxiliar na apreensão das identidades nas organizações, uma vez que em sua concepção, a definição de Albert e Whetten (1985), se utilizada de maneira isolada, seria restrita, no sentido de representar algo que a organização possui, não o que ela é. Assim, Wood Júnior e Caldas (1995) enfatizam que a abordagem linguística, mais especificamente por meio do conceito de metáfora-raiz, identificar-se-ia com a noção de visão de mundo dos atores organizacionais e traria à tona a geração de insights sobre o que é a organização e como ela é percebida pelos diferentes membros que com ela interagem. Assim, seria possível inferir que estes autores se posicionam a partir de uma forma de observação interna, ou seja, baseada em como o indivíduo ou grupo se vê.

Em estudo posterior, Caldas e Wood Júnior (1997) ampliam seus estudos, após uma ampla revisão das pesquisas acerca do tema "identidade", e propõem um agrupamento com base em seis grandes diferentes escolas:

1a) estudos pioneiros em identidade individual, de Erikson, de origem psicanalítica, com foco na identidade individual expressa (comportamento);

2a) estudos em psicologia social, que relacionam identidade individual e identidade grupal por meio do conceito de identificação;

3a) estudos derivados da identidade individual transpostos para o campo organizacional, cuja base é o trabalho de Albert e Whethen (1985);

4a) estudos do final dos anos 1980 e início dos anos 1990 derivados dos conceitos de psicologia social, que desenvolvem estudos sobre a relação entre identificação organizacional e autoconceito individual;

5a) estudos sobre identidade organizacional como imagem corporativa, oriundos da instrumentalização da análise da identidade como uma perspectiva externa à organização; e

6a) estudos sobre identidade em nível macro, influenciadas por ideias pós-modernistas e pelo questionamento da existência de um self humano.

O mérito dessa nova abordagem foi, sem dúvida, mapear o campo da identidade e com isso possibilitar aos pesquisadores melhor compreendê-lo, ao nele se situarem. Contudo, uma de suas limitações consiste no possível reducionismo em que se pode cair em toda sistematização - como bem explicitam os próprios autores. Em meio a essa discussão sobre o tema identidade lançada no cenário brasileiro, outros autores tentaram proporcionar classificações alternativas, como Machado (2003) e Machado e Kopittke (2002), ao sintetizarem quatro perspectivas para a sistematização do estudo de identidades nas ciências sociais. Isso contribui para se entender o direcionamento do campo nos estudos organizacionais como um tipo específico, a saber:

1a) identidade pessoal - considerada a construção do autoconceito ao longo da vida de um indivíduo, por meio de diversos relacionamentos sociais em diversas esferas, levando à conformação do $e u$, em direção ao processo de individuação; 
2a) identidade social - entendida a partir da formação do autoconceito pela vinculação a grupos sociais, por meio da interação com esses diversos grupos;

3a) identidade no trabalho - refere-se à construção do $e u$ pela atividade que realiza e pelas pessoas com as quais se tem contato, mediante a interação com a atividade e com as pessoas no trabalho;

4a) identidade organizacional - corresponde à construção do conceito de identidade do grupo social, como se fosse uma entidade autônoma, um "sujeito", que vincula e subordina os demais sujeitos participantes do grupo a essa identidade, fazendo-os aceitá-la (pelo menos, implícita e tacitamente), ao vincularem-se à organização onde trabalham.

Embora relevante, seja pelo fornecimento de uma alternativa seja pela ampliação do debate sobre identidade, a baixa disseminação e a falta de aprofundamento por outros autores, sobretudo, no que tange ao estabelecimento de categorias operacionais ou analíticas, em relação a essa perspectiva fez com que o debate se restringisse ao "bom e velho" modelo de Albert e Whetthen (1985), que supria tal lacuna ao oferecer as variáveis necessárias à verificação empírica da identidade organizacional. A partir daí, com raras exceções, como Carrieri (2001a, 2001b), pouco foi feito para expandir e inovar os estudos sobre identidade organizacional no EO's brasileiros.

Wood Júnior e Caldas (2006), retomando mais uma vez essa temática, buscam revisitar os estudos sobre identidade tentando observar o grau de evolução que eles tiveram transcorridas mais de duas décadas do estudo seminal de Albert e Whetten (1985). Segundo os autores, muitas linhas de pesquisa foram desenvolvidas, em diversos níveis de análise, passando do estudo da identidade numa perspectiva de "identidade de" para uma perspectiva de "identidade dentro" e de "identidade em torno" das organizações, ultrapassando os limites da clássica definição original. Assim, argumentando que a diversidade na academia, apesar de ser positiva, poderia gerar confusão e perda de sentido dos termos quando não mapeada e organizada, e de que as poucas tipologias existentes tenderiam a encarar o fenômeno de modo parcial e com poucas variáveis, Wood Júnior e Caldas (2006) propuseram a compilação e um novo mapeamento das diversas definições e correntes existentes. Isso os leva à construção de uma estrutura conceitual composta dos cinco principais elementos constituintes das diversas definições e perspectivas de estudo do termo identidade.

Assim, Wood Júnior e Caldas (2006) propõem um modelo de cinco dimensões de análise de identidade (fivering framework of identity), com base em uma visão panorâmica e sintética das cinco principais dimensões de análise das identidades nas organizações:

1ạ dimensão: nível de análise (ou objeto focal) - responsável por distinguir a possibilidade de se focar distintos objetos, como, por exemplo, indivíduos, grupos, organizações, redes de organizações e sociedades;

2ạ dimensão: unidade de observação - aqui se coloca a seguinte questão: por quem ou de que forma a identidade está sendo analisada? Nesse sentido, haveria várias formas de estudar a identidade, podendo-se comprendê-la como uma capacidade inata, tanto do indivíduo quanto da organização (dependeria da definição da dimensão anterior), passando pelo entendimento da identidade como internamente definida (ou seja, autopercebida), até se chegar a sua definição como externamente observada;

3a dimensão: o critério de centralidade - aqui se discute a concepção de identidade como uma extensão em um continnuum entre dois polos: de um lado, a centralidade e, de outro, as múltiplas identidades. Inicialmente, a definição de Albert e Whetten (1985) - derivada de Erikson (1976) - considerava que a centralidade corresponderia à essência da organização. Diante das diversas contribuições de estudos posteriores, dentre as quais se destacam as da corrente sociopsicológica, reconheceu-se a noção de múltiplas identidades, a qual prega que a organização pode ter não uma, mas várias identidades, de acordo com a sua relação de significado com os outros e também da mudança de identidade em virtude do próprio contexto;

4a dimensão: critério de distintividade - essa característica, a priori, define a diferença de uma organização em relação às outras. Há uma inadequação desse critério clássico para os dias atuais, pois a emergência de formas virtuais vem fazendo com que as fornteiras venham se tornando cada vez mais permeáveis e flluidas; e 
5a dimensão: continuidade temporal - de um lado, pode-se observar o entendimento desse critério como uma capacidade da identidade resistir à erosão ao longo do tempo. De outro lado, surge o conceito de identidade como um processo fluido, conforme destaca Bauman (2005). Um exemplo é a análise de Hall (2005) sobre o descentramento da identidade do sujeito moderno, que vem se tornando cada vez mais fluido, dinâmico, segundo o aumento da velocidade do tempo de giro da esfera da produção e do consumo (HARVEY, 2000), mediado pela linguagem.

Enquanto as duas primeiras dimensões são ontológicas, as três últimas referem-se a dimensões conceituais. Estas fazem uma distinção entre as diferentes perspectivas de base teórica sobre o construto identidade. No entanto, todas as cinco dimensões estariam enquadradas em um continuum, conforme a figura a seguir (WOOD JÚNIOR; CALDAS (2006).

Figura 1 - As cinco dimensões de análise da identidade

Dimensão da Centralidade

Distinto

Dimensão de Observação

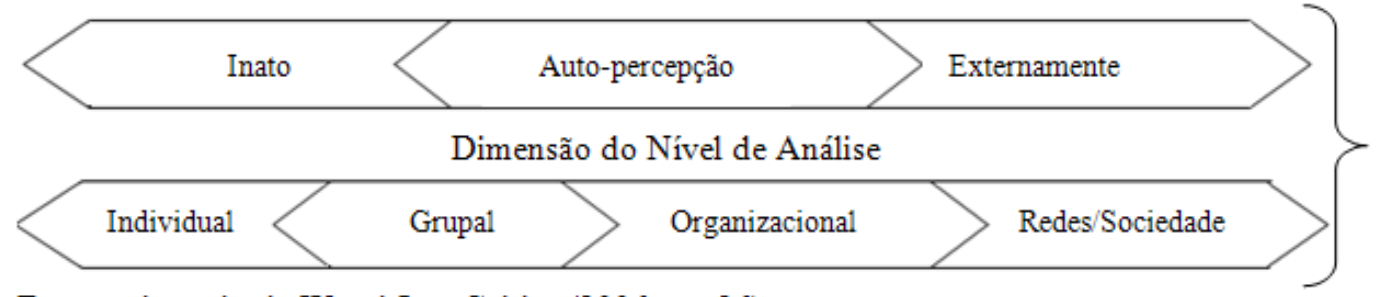

Dimensões Ontológicas

Fonte: adaptado de Wood Jr. e Caldas (2006a, p. 36).

A argumentação de Wood Júnior e Caldas (2006) é a de que, em seu conjunto, as cinco dimensões fornecem um quadro conceitual mais rico e amplo sobre as abordagens existentes, permitindo aos pesquisadores localizarem-se e, ao mesmo tempo, combinarem as diferentes dimensões, a fim de produzirem novas propostas de pesquisa e, com isso, desenvolverem o campo. Na visão deles, qualquer pesquisador que alinhasse as seguintes dimensões:

a) o nível organizacional de análise;

b) a definição interna de identidade;

c) a alta centralidade (ao invés da multiplicidade);

d) a alta diferenciação; e

e) a alta capacidade de resistência ao longo do tempo (continuidade temporal), obteria o clássico modelo de Albert e Whetten (1985).

Por outro lado, outras possibilidades de combição poderiam orientar a condução de diferentes estudos. Por exemplo, a combinação dos elementos: 
a) nível interorganizacional;

b) dimensão de múltiplos pontos de vista;

c) alta multiplicidade de identidade;

d) indistintividade (ou seja, limites confusos e superpostos); e

e) a baixa continuidade temporal,

levaria a uma situação de análise de conglomerados de organizações indiferenciadas em seu ambiente e em constante mudança na tentativa de se adequar ao ambiente organizacional.

Assim, o trabalho dos autores, apesar da contribuição no que tange à organização do arcabouço teórico já existente - permitindo aos pesquisadores localizarem-se com maior precisão e obsevarem as diversas correntes e concepções existentes, bem como os gaps e as brechas para futuros estudos (ampliação do campo) -, pode camuflar perspectivas internas (nas fronteiras entre uma corrente e outra), a natureza de cada grupo de autores e suas perspectivas teóricas, além do não questionamento das assunções básicas a partir das quais se constrói o conceito de identidade (WOOD JÚNIOR; CALDAS, 2006).

Além dessa autocrítica, outras questões devem ser aprofundadas. É o caso do viés estruturalista do modelo que pretende contemplar as explanações sobre o estudo de identidade apenas mesclando, de diferentes formas, categorias que já vêm sendo trabalhadas há muito tempo no estudo de identidade, o que limita o campo em termos de sua potencialidade de exploração, já que esse modelo fechado deixa de incorporar categorias e fenômenos que poddem não se enquadrar nessas dimensões de análise, embora contribua de algum modo para a compreensão do fenômeno da identidade. Assim, apesar de bem estruturado, o modelo proposto pelos autores como síntese do l'etat d'art do desenvolvimento conceitual das pesquisas de identidade deixa a desejar, sobretudo, quando se constata uma carência de desenvolvimentos conceituais recentes sobre o tema, não tendo sido acrescentada aos estudos nenhuma nova categoria conceitual ou analítica, pelo menos, desde o estudo de Albert e Whetten (1985).

Assim, os estudos sobre o tema apresentam uma limitação - evidenciada desde o modelo de Albert e Whetten (1985), propagando-se até a elaboração do modelo de Wood Júnior e Caldas (2006a) - que é dissociar a dimensão de tempo da de espaço, enfatizando a dimensão da temporalidade como constitutiva da identidade, em detrimento da dimensão da espacialidade, como se as duas fossem completamente independentes.

Vários estudiosos têm escrito sobre identidade, especificamente, no campo organizacional, mas, com raras exceções (BORZEIX; LINHART, 1996; CARRIERI, 2005; FISCHER, 1994; GOMES-da-SILVA, 2005, 2006; GOMES-da-SILVA; WETZEL, 2006), tem sido comum a displicência ou omissão deliberada no que tange à questão do espaço e sua relação com a construção da identidade. Nesse sentido, é impotante resgatar os apontamentos de estudos clássicos de outras áreas (BOURDIEU, 2002, CASTELLS, 1979; CERTEAU, 1990; FOUCAULT, 1989; LEFEBVRE, 1999; SANTOS 1997) que já evidenciavam de forma embasada essa relação.

Nesse sentido, reconhecendo as contribuições da sistematização desenvolvida por Wood Júnior e Caldas (2006), mas ao mesmo tempo tentando transcendê-las, é apresentada na próxima seção uma introdução à questão da dimensão espacial.

\section{Espacialidade na construção da identidade: uma proposta analítica teórico-empírica}

Santos (1997) considera que toda organização do espaço pressupõe uma organização social do mesmo. Toda divisão do espaço pressupõe uma divisão social, e toda divisão geográfica remete a uma divisão social do trabalho. Assim, a organização do espaço não é apenas a configuração de uma forma peculiar, dentre muitas, em que as interações sociais ocorrem, mas ela própria, em si mesma, estrutura essas interações. Isso ocorre porque, concordando com Lefebvre (1991), o espaço não é neutro, mas, sim, política e ideologicamente demarcado, traduzindo, em última instância, as coerções que o grupo dominante lhe impõe e impõe aos grupos 
socialmente dominados. É justamente nesse sentido que Castells (1979) falará da historicidade das relações sociais materializadas no espaço. Dessa forma, o espaço é importante porque, ao mesmo tempo, é o lócus indispensável de existência da vida material, oferecendo tanto as possibilidades de constrangimento dos corpos (FOUCAULT, 1989) - e, portanto, de controle e dominação - quanto de emancipação e liberação dos indivíduos (LEVEBVRE, 1991). Somente por meio de uma (re)organização socioespacial é que se torna possível o estabelecimento de uma ou de outra situação.

Tal constrangimento evidencia, justamente, a apropriação dos espaços por determinados grupos sociais, sejam grupos dominantes - que têm o domínio de um espaço próprio e por isso desenvolvem estratégias de regulação e manutenção do seu controle sobre o espaço- sejam grupos dominados, que buscam desenvolver táticas de subversão dos usos e sentidos dos espaços, especialmente, aproveitando-se de oportunidades espaçotemporalmente delimitadas, a fim de reelaborar e efetuar bricolagens naquele espaço, apropriando-se, mesmo simbolicamente, do mesmo (CERTEAU, 1990).

Vale ressaltar aqui duas questões fundamentais: de um lado, a prática de apropriação do espaço, seja ela física ou simbólica, e, de outro, o consequente processo que essa prática desencadeia, que é a dominação política e ideológica de determinadas espaços - físicos ou simbólicos - e possíveis restrições ao acesso de outros. Ao considerar-se a apropriação do espaço, parte-se do pressuposto de que alguém se apropria dele (AGNEW, 1994). Por extensão, podemos inferir que esse processo de apropriação fará com que o espaço seja dotado de (pelo menos) uma característica de demarcação, que o diferencia de um espaço não demarcado, por ter essa(s) característica(s) de quem dele se apropria. Nesse sentido, é importante frisar que apropriação não implica necessariamente exclusão.

Portanto, essa apropriação envolve a incorporação do espaço físico pelo indivíduo, atribuindo-lhe significados subjetivos e, dessa forma, traduzindo-se no uso desse espaço carregado de marcas individuais e identitárias (FISCHER, 1994). Assim, a apropriação está intimamente ligada à maneira como o espaço é incorporado pelo indivíduo, que, por sua vez, irá caracterizá-lo de acordo com seus traços e marcas pessoais e identitários. Segundo Gomes-da-Silva e Wetzel (2006, p.5), a incorporação do espaço

[...] trata-se de um conceito não relacionado apenas ao espaço material ao redor do corpo, à esfera que contém os movimentos ou atividades físicas, mas também às distâncias mantidas nas relações sociais [pelas quais] os indivíduos tendem a preservar o seu espaço pessoal e a definir a sua forma de interação com os outros, [o que varia] em função da personalidade dos sujeitos, de fatores individuais, tais como idade e status social, de fatores interpessoais, tais como atração, de fatores situacionais (elementos físicos ligados ao contexto) e [de] fatores culturais.

Uma primeira forma de apropriação do espaço é aquela baseada na apropriação exclusivista, derivada da ideologia da competição natural entre os homens (HOBBES, 1988). Dessa forma inicial, derivam-se as formas de apropriação coletiva, as quais são consideradas no quadro de referência da forma de relacionamento espacial objetivada pela territorialidade, onde Staub (2004) evidencia como essas práticas estão relacionadas com a perspectiva simbólica, em especial, com o uso da linguagem.

Para esse autor, os indivíduos, ao relacionarem-se socialmente com os outros num determinado espaço, estariam sempre desempenhando papéis de correntes de sua posição nesse determinado contexto social. Assim, no estudo da ação social, um indivíduo relaciona-se com outro que está embebido na estrutura social e na estrutura da ação territorial, sendo a interação sempre tridimensional, já que o que está em jogo é a relação entre um indivíduo e outro na disputa por um dado território, estabelecendo-se uma dicotomia entre inclusão e exclusão materializada pela conquista ou defesa de um território por aqueles agentes. Formam-se, assim, os três elementos básicos daquilo que o autor denomina de "estrutura de análise territorial" (STAUB, 2004).

A territorialidade é estruturada pelas relações territoriais de inclusão/exclusão e por entidades precisas indivíduo, outro e território -, estabelecendo, numa relação tridimensional e simultânea, a oposição entre indivíduo-outro e as relações excludentes de interesse indivíduo-território e outro-território. Para esse autor, tal análise seria verificada por meio da palavra do indivíduo, que sempre contém a sua própria (o)posição em 
relação ao outro. Assim, enquanto uns tentam conquistar, outros tentam defender, girando sempre tal análise em torno da questão da posse, sendo, portanto, seu principal traço distintivo a competição (STAUB, 2004).

Contudo, para esse autor, a análise da dimensão espacial resume-se à exploração da competição por espaços físicos e simbólicos, materializada pela noção de territorialidade. Nesse sentido, outra possibilidade de estudo a da cooperação e utilização do mesmo espaço em conjunto - é omitida, induzindo ao raciocínio de que os indivíduos, ao apropriarem-se, identificarem-se e relacionarem-se com os espaços, fariam isso apenas de modo competitivo e exclusivista. Essa apropriação denotativa da própria expressão individual de estar e fazer parte do mundo é uma prática social que se traduz pela demarcação, apropriação e personalização do espaço ou, como correntemente denominado, pela territorialização do espaço.

É importante salientar que toda territorialização (e seu movimento inverso, a desterritorialização) pressupõe uma espacialidade, embora nem toda espacialidade corresponda à territorialização do espaço. Isso porque a territorialização pressupõe práticas de apropriação e exclusão, tendo como lógica subjacente a competição. Já a espacialidade como prática social de relacionamento com o espaço pressupõe somente apropriação. Esta pode ocorrer, por exemplo, de forma compartilhada (no caso de bens públicos) ou simbólica, em relação a bens e espaços, como ocorre no turismo. A diferença, que parece apenas semântica, traduz-se de maneira mais contundente quando se analisa, por exemplo, a polaridade entre espaços públicos e privados. Enquanto aqueles estão submetidos à lógica de apropriação coletiva e da solidariedade (ROUSSEAU, 2006), que reforça os laços entre os membros de uma comunidade, já que todos podem se apropriar de algum comum; estes últimos (espaços privados) pressupõem uma lógica de apropriação por meio da exclusão, onde algo só pode ser apropriado se for expropriado de outros. Reconhece-se aqui a relevância da apropriação do espaço pela lógica da exclusão. Contudo, ela faz parte de um quadro mais amplo de relações sociais com o espaço - da "espacialidade" - (SOJA, 1998), que tende a promover uma lógica de apropriação não necessariamente de exclusão, mas, antes, inclusiva.

No esquema teórico de análise formulado a seguir, considerou-se para este estudo a espacialidade como prática de produção do espaço social e dimensão de análise do mesmo, visto que a mesma compreenderia uma visão mais ampla das formas de relacionamento com o espaço, enquanto a territorialidade focaria apenas um dos seus aspectos. Dessa forma, a espacialidade (ou dimensão espacial) foi considerada um conjunto de práticas sociais que manifestam a forma de relacionamento com o espaço físico e simbólico (sua representação mental), sendo o espaço propriamente dito constituído por um conjunto de objetos e sistemas de ação (SANTOS, 1997). Os objetos seriam formas ou estruturas materiais e concretas já existentes no espaço de forma natural (ou seja, resultado do efeito cumulativo da ação das condições ambientais durante milhões de anos) ou de forma artificial (quando construídos pelo próprio homem). Já os sistemas de ação seriam um conjunto de ações sociais estruturadas sob uma determinada dinâmica, como as ações econômicas, políticas, institucionais ou jurídicas (CASTELLS; 1979) - consideradas então como sistemas, que manifestam a ação dos indivíduos sobre o espaço.

Essas ações, a despeito de uma ampla gama de variações possíveis, foram especificadas para a finalidade deste artigo de quatro formas:

a) a organização do espaço - diz respeito à forma como o espaço se apresenta em um dado momento. Quais são seus elementos fixos e de que forma eles estão dispostos (SANTOS, 1997)? Ou de que forma elementos fixos estão dispostos no processo organizativo? Como eles operam na construção da identidade? Essa organização é uma visão momentânea do espaço que irá representar um período espaço-temporalmente delimitado, mas não quer dizer que o espaço se limite àquilo. Por isso, é necessário compreender que há uma dinâmica na produção do espaço. Se o espaço se apresenta de tal forma em um dado momento, é porque uma série de ações foram efetuadas no sentido de "configurá-lo" daquele jeito. Desse modo, para compreender essa dinâmica é necessário não apenas considerar complementarmente (e aqui entra a perspectiva da temporalidade da identidade) uma perspectiva histórica e longitudinal, mas também levar em conta outros elementos que contribuem para a sua formação. 
b) a circulação de fluxos - refere-se ao modo como diferentes objetos e indivíduos se deslocam pelo (e no) espaço. A questão aqui é compreender a dinâmica de circulação em um dado espaço. Isto é: quais são os fluxos circulantes? De onde eles saem e para onde se dirigem? Que elementos concretos/objetivos e simbólicos/subjetivos são passíveis de circulação (mudança de disposição temporária) dentro do universo organizacional? Qual a relação entre esses elementos, sua dinâmica e a dotação de subjetividade/demarcação subjetiva da realidade objetiva pelos indivíduos? Notadamente, a dimensão econômica (dos fluxos financeiros) constitui o principal elemento de análise, pois é por meio dela que se flexibiliza (ou tenta-se flexibilizar) a circulação de outros elementos, até então fixados no espaço (SANTOS, 1997). Contudo, isso não reduz a análise da circulação de fluxos à dimensão econômica. É possível analisar como objetivos e práticas sociais podem percorrer diferentes espaços da organização, identificando e socializando os indivíduos e, também, estabelecendo fronteiras entre os estabelecidos e os outsiders, sobretudo, pelas possibilidades de abertura ou restrição em termos do espaço a que estes podem ter acesso.

c) as práticas de apropriação-exclusão - concernem às formas pelas quais determinado espaço é tomado, apropriado e usado por um indivíduo ou grupo social que veda a outros indivíduos ou grupos a possibilidade de utilização desse mesmo espaço (AGNEW, 1994). Tais práticas implicam necessariamente a restrição de acesso de certos indivíduos e grupos sociais a determinados espaços, como maneira de se estabelecer uma fronteira e uma diferenciação entre tais grupos. Trata-se de uma demarcação simbólica entre nós e eles, que no processo organizativo se verifica em grande parte pelas hierarquias funcionais, pelo estabelecimento de papéis sociais e pela ocupação de determinados espaços "compatíveis" com tais atividades. Ressalta-se que tais expectativas, práticas e espaços - numa concepção foucaultiana (ALCADIPANI, 2005) - são produzidos pelo poder.

d) a percepção do espaço - refere-se à forma como o espaço é apropriado e representado, simbólica e cognitivamente, por um dado indivíduo ou grupo social (SOJA, 1998). Aqui, a sua principal característica é a forma como os indivíduos ou grupos sociais manifestam as suas experiências particulares com o espaço em questão, evidenciando, então, o espaço vivido por um conjunto de atores sociais. A memória coletiva e as produções simbólicas são ao mesmo tempo o produto dessa percepção do espaço e os elementos que permitem a sua manutenção no plano coletivo ser compartilhada por uma miríade de indivíduos e grupos, significando, assim, uma possibilidade de acesso aberta a estes atores.

São esses elementos que se considera que devem compor (como categorias analíticas de verificação empírica) a dimensão espacialidade. Esta, por sua vez, deve ser inserida como uma dimensão conceitual - assim como a centralidade, a distintividade e a temporalidade - constituinte do conceito de identidade. Envolver essas quatro dimensões contemplaria a possibilidade de definição de duas dimensões ontológicas do estudo da identidade (WOOD JÚNIOR; CALDAS, 1995, 2006): a dimensão do objeto focal (se individual, grupal ou organizacional) e a dimensão da orientação da observação (se interna ou externamente definidas). Essas dimensões, por serem consideradas ontológicas são definidas a priori e, portanto, situam o estudo das demais dimensões apresentadas anteriormente e suas limitações.

Por fim, envolvendo tanto as dimensões conceituais quanto as ontológicas, este estudo considera a existência de um contexto sócio-histórico e cultural (BORZEIX; LINHART, 1996; NKOMO; COX JÚNIOR, 2001) que serviria de parâmetro para orientar tanto as formas de relacionamento com o espaço quanto a própria construção da identidade. Dessa forma, é nesse contexto que as possíveis configurações espaciais e identitárias (identitária espacializada) adquiririam sentido, formando as zonas de consenso (REY, 2005) e, portanto, poderiam ser confirmadas e legitimadas ou refutadas e reformuladas. Assim, um caminho de pesquisa pode ser sugerido, por exemplo, a partir do seguinte esquema teórico-metodológico (figura 2). 
Figura 2 - Esquema teórico de análise de identidade incorporando a dimensão do espaço

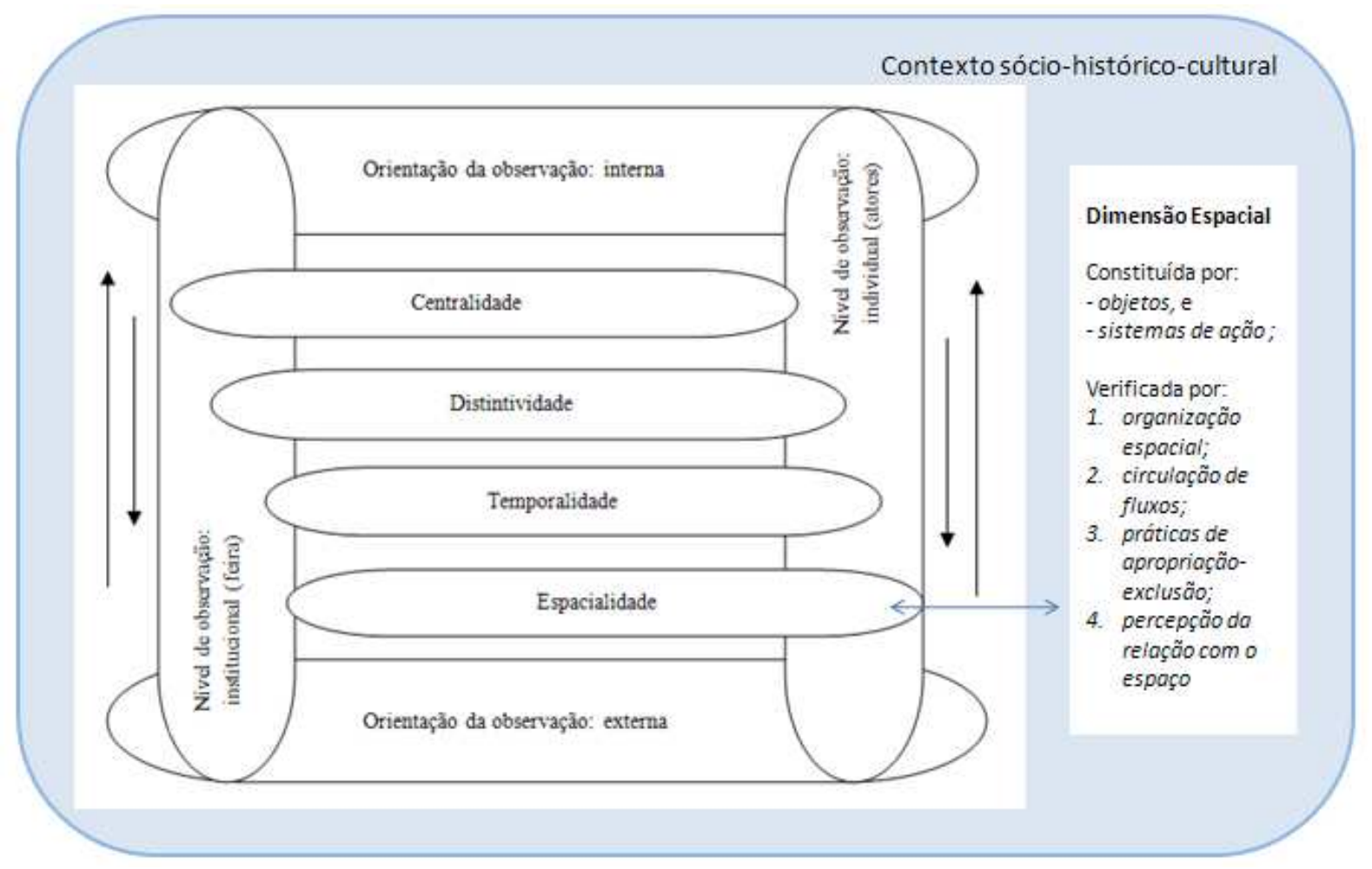

Fonte: elaborado pelos autores, a partir do modelo de Wood Júnior e Caldas (2006).

\section{Reflexões parciais em busca da legitimação da espacialidade na construção de identidade}

Quando se faz uma retrospectiva analítica sobre o estado da arte do tema identidade dentro do campo dos estudos organizacionais brasileiros, evidenciando sua evolução e principais limitações, é possível identificar a ausência de desenvolvimentos conceituais nos últimos 25 anos. Tal fato corrobora o objetivo de propor a adoção, tanto de uma perspectiva conceitual quanto analítica, da dimensão espacial (ou espacialidade) nos estudos sobre identidade no processo organizativo.

Nesse sentido, ao propor (ainda que de modo incipiente e inicial) a adoção da dimensão espacial como categoria conceitual analítica do fenômeno social da identidade para os EO's (especialmente, brasileiros), este estudo tenta contribuir para a ampliação das pesquisas sobre o tema em questão. Várias aproximações, em diferentes graus de sistematização, já haviam sido apontadas por autores como Carrieri e Pereira (2003), Gomes-da-Silva (2006), Vergara e Vieira (2003) e Staub (2004), sobretudo, a partir das concepções de vários estudiosos do campo da geografia, como Lefebvre (1991), Santos (1997) e Soja (1998).

A contribuição aqui proposta para os estudos organizacionais vai além do entendimento da dimensão do espaço como uma categoria analítica. O que este artigo aponta e defende é uma revisão parcial do conceito clássico de identidade organizacional proposto por Albert e Whetten (1985), através da incorporação de uma nova categoria conceitual: a espacialidade. Essa categoria, como proposta inicial (ver figura 2), poderia ser definida como aquilo que se manifesta fisicamente no espaço, por meio de objetos e sistemas de ação e, simbolicamente, por meio de sua representação mental, sendo operacionalizada pela verificação dos seguintes elementos:

a) organização espacial - como estão organizados os objetos e os sistemas de ação num dado espaço físico; 
b) a circulação de fluxos - qual a dinâmica por trás da organização dos objetos e sistemas de ação que organizam o espaço;

c) práticas de apropriação/exclusão - que representariam no plano do espaço físico a ordem dominante na organização do espaço e, no plano simbólico, a dimensão política e afetiva da materialização dessa ordem, isto é, como e por quem o espaço é usado e apropriado e o que e quem estão alijados daquele espaço como consequência do processo de uso e apropriação; e

d) a própria percepção do espaço como dimensão simbólica e ideológica propriamente dita - que refletiria o modo pelo qual os indivíduos leem, interpretam e interagem com o espaço. Essa dimensão simbólica, ou percepção do espaço, está diretamente relacionada à noção de espaço representacional de Lefebvre (1991).

Assim, a espacialidade seria mais uma dimensão conceitual e analítica do conceito de identidade organizacional (ou no processo organizativo), que, por sua vez, poderia ser redefinido da seguinte forma:

a) é aquilo que é central - que representa a finalidade essencial do grupo social, a sua razão de existir;

b) distintivo - isto é, que permite ao grupo social (ou organizacional) se distinguir dos outros grupos que lhes são semelhantes (em parte, devido a sua característica central);

c) temporal - que se refere ao fato de ter uma relativa estabilidade temporal, a ponto de fornecer uma coerência histórica ao grupo; e

d) espacial - que diz respeito à configuração da dinâmica de manifestação física e concreta pela qual essa identidade se expressaria, seja pela sua manipulação do espaço físico, por meio de estratégias de apropriação e territorialidade, seja pela sua manifestação simbólica (mas que, em última instância, contribuiria para ordenar a ordem material), que se dá pela percepção do espaço e pelas formas de interação e veiculação de ideias e imagens sobre este.

Obviamente, essa proposição teórica de conceituação e análise da identidade no processo organizativo não é definitiva. Pelo contrário, apenas inicia-se aqui um possível caminho para a exploração do tema, o que, certamente, irá requerer a realização de diversos estudos. O que se fez até aqui foi identificar uma lacuna nos estudos sobre identidade, a saber: a ideia de sua construção no "vácuo", ou seja, sem necessariamente estar inserida em um dado espaço, que, por sua vez, estaria inserido num contexto mais amplo.

Por fim, ainda existe uma limitação em termos da proposição desse esquema teórico de análise da identidade, com a agregação da dimensão espacial de análise. Nesse sentido, por ser apenas uma proposição, torna-se necessária a realização de novos estudos, tanto qualitativos quanto quantitativos, que envolvam esse esquema teórico, a fim de verificar se o seu potencial explicativo, de fato, contribui para o campo dos estudos organizacionais e, em especial, para a análise dos estudos de identidade no processo organizativo, seja grupal, organizacional e/ou institucional.

\section{Referências}

AGNEW, J. A. Territory and territoriality. In: JOHNSTON, R. J.; GREGORY, D.; SMITH, D. M. (Ed.) The dictionary of human geography. 3th ed. Oxford: Blackwell Publishers, 1994. p.620.

ALBERT, S.; WHETTEN, D. A. Organizational identity. Research in Organizational Behavior, London, v.7, p.263-295, 1985.

ALCADIPANI, R.; ALMEIDA, A. Por fora bela viola, por dentro...: análise crítica sobre a gestão do espaço nas organizações, através de um estudo de caso sobre a implementação de um escritório aberto no Brasil. Organizações \& Sociedade, v.6, n.19, set./dez. 2000. 
ALCADIPANI, Rafael da S. Michel Foucault: poder e análise das organizações. Rio de Janeiro: Editora FGV, 2005. p. 168

ALMEIDA, A. L. de C. A influência da identidade projetada na reputação organizacional. Tese (Doutorado) apresentada ao Centro de Pós-Graduação e Pesquisas em Administração (CEPEAD) da Universidade Federal de Minas Gerais (UFMG). Belo Horizonte, março de 2005. (p.16-52).

ALMEIDA, A. L. de C; BERTUCCI, J. L. de O. O Impacto da Identidade Projetada na Identificação dos Empregados com a Organização: O Caso da Fundação Dom Cabral. In: ENCONTRO NACIONAL DE PROGRAMAS DE PÓS GRADUAÇÃO EM ADMINISTRAÇÃO, 31., 2007, Rio de Janeiro. Anais... Rio de Janeiro: Anpad, 2007. 1 CD-ROM.

ARONDEL-ROHAUT, M. Exercícios filosóficos. São Paulo: Martins Fontes, 2000. 137p.

BAUER; M. A. L.; MESQUITA, Z. As concepções de identidade e as relações entre indivíduos e organizações: um olhar sobre a realidade da agricultura ecológica. RAC Eletrônica, v.1, n.1, p.16-30, jan./abr. 2007.

BAUMAN, Z. Identidade: entrevista a Benedetto Vecchio. Rio de Janeiro: Jorge Zahar, 2005.

BERGER, P.; LUCKMANN, T. A construção social da realidade: tratado de sociologia do conhecimento. Tradução: Floriano de Souza Fernandes. 24.ed. Petrópolis: Vozes, 2004.

BORZEIX, A.; LINHART, D. Identidades e práticas linguísticas na empresa. In: CHANLAT, J.-F. (Org.). 0 indivíduo na organização: dimensões esquecidas. São Paulo: Atlas, 1996. v.III, p.82-106.

BOURDIEU, P. O poder simbólico. 5.ed. Rio de Janeiro: Bertrand Brasil, 2002.

CALDAS, M. P.; WOOD JÚNIOR, T. Identidade organizacional. Revista de Administração de Empresas - RAE, São Paulo, v.37, n.1, p.6-17. jan./mar. 1997.

CARRIERI, A. de P. O fim do "Mundo Telemig": a transformação das significações culturais em uma empresa de telecomunicações. Tese (Doutorado em Administração) -Universidade Federal de Minas Gerais, Belo Horizonte, 2001a.

As metáforas de identidade de uma empresa de telecomunicações antes e depois de sua privatização. In: ENCONTRO NACIONAL DE PROGRAMAS DE PÓS-GRADUAÇÃO E PESQUISA EM ADMINISTRAÇÃO, 25., 2001, Campinas. Anais... Campinas: Anpad, 2001b.

. A transformação das identidades em uma empresa de telecomunicações antes e depois de sua privatização: um estudo de metáforas. Organizações \& Sociedade, v.9, n.23, p.13-34, 2002.

Estratégias delineadas na construção das identidades em organizações familiares: um estudo dos expositores da "Feira Hippie" de Belo Horizonte. Relatório final de pesquisa submetido ao Conselho Nacional de Desenvolvimento Científico e Tecnológico (CNPq). Ministério da Ciência e Tecnologia, Brasil - Processo no 402786/03-3, 2005.

; PEREIRA, Denise. C. Movimento de desterritorialização e reterritorialização na transformação cultural: um estudo

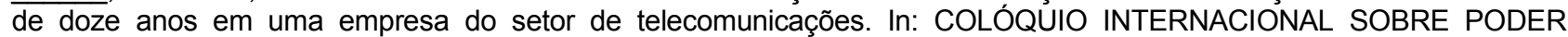
LOCAL, 9., 2003, Salvador. Anais... Salvador: Escola de Administração - EAUFBA, 2003.

CASTELLS, M. Problemas de investigação em sociologia urbana. Lisboa: Editora Presença, 1979.

CERTEAU, M. L'invention du quotidien - 1'arts de faire. Paris: Editions Gallimard, 1990.

CORRÊA, H. L.; GIANESI, I, G. N. Just in time, MRP e OPT: um enfoque estratégico. São Paulo: Atlas, 1996.

ERIKSON, E. H. Identidade, juventude e crise. Tradução: Álvaro Cabral. 2.ed. Rio de Janeiro: Zahar Editores, 1976. 323p.

ÉSTHER, Â. B. A construção da identidade gerencial dos gestores da alta administração das universidades federais de Minas Gerais. Tese (Doutorado) - Centro de Pós-Graduação e Pesquisas em Administração (Cepead), Universidade Federal de Minas Gerais (UFMG). Belo Horizonte, 2007.

FISCHER, G. Espaço, identidade e organização. In: CHANLAT, J. F. (Org.). O indivíduo na organização: dimensões esquecidas. São Paulo: Atlas, 1994. v.II, p.81-102.

FORD, H. Minha Vida, Minha Obra. Rio de Janeiro: Brand, 1954.

FOUCAULT, M. Vigiar e punir: nascimento da prisão. Petrópolis: Vozes, 1989.

GOFFMAN, E. Estigma: notas sobre a manipulação da identidade deteriorada. Tradução: Márcia Bandeira de Mello Leite Nunes. Rio de Janeiro: Zahar Editores, 1975. (Coleção Biblioteca de Antropologia Social).

GOMES-da-SILVA, J. R. Profissionais Qualificados e Experiências de Auto-emprego: Questões de Tempo e Espaço. In: Encontro Nacional de Programas de Pós-Graduação e Pesquisa em Administração, 30. 2006, Salvador. Anais... Salvador: ANPAD, 2006. (CD-ROM). 
GOMES-da-SILVA, J. R. WETZEL, U. A construção de um quadro analítio sobre as significações de espaço no contexto das mudanças organizacionais. In: ENCONTRO NACIONAL DE PROGRAMAS DE PÓS-GRADUAÇÃO E PESQUISA EM ADMINISTRAÇÃO, 30., 2006, Salvador. Anais... Salvador: Anpad, 2006.

HALL, S. A identidade cultural na pós-modernidade. Tradução: Tomaz Tadeu da Silva e Guacira Lopes Louro. 10.ed. Rio de Janeiro: DP\&A Editora, 2005.

HARDY, C; LAWRENCE, T. B.; GRANT, D. Discourse and collaboration: the role of conversations and collective identity. Academy of Management Review, v.30, n.1, p.58-77, 2005.

HARVEY, D. A condição pós-moderna: uma pesquisa sobre as origens da mudança cultural. São Paulo: Loyola, 7ed. 2000.

HATCH, M. J.; SCHULTZ, M. Introduction: Why study organizational identities? In: Organizational identity: a reader. New York: Oxford University Press Inc., 2004. p.1-6.

HERÁCLITO. Fragmentos: a origem do pensamento. Edição bilíngue com tradução, introdução e notas de: Emmanuel Carneiro Leão. Rio de janeiro: Editora Tempo Brasileiro, 1980.

HOBBES, T. O Leviatã. Tradução: João Paulo Monteiro e Maria Beatriz Nizza da Silva. São Paulo: Editora Nova Cultural, 1988. (Coleção Os Pensadores).

LALANDE, A. Vocabulário técnico e crítico da filosofia. Porto: Rés Editora, [1985].

LEFEBVRE, H. The production of space. Oxford: Blackwell, 1991.

. A revolução urbana. Belo Horizonte: Editora da UFMG, 1999. 178p.

LOPES, José Rogério. Os caminhos da identidade nas ciências sociais e suas metamorfoses na psicologia social. Psicologia Social, Belo Horizonte, v.14, n.1, jun. 2002.

McKINNEY, J. P.; FITZGERALD, H. E.; STROMMEN, E. A. Psicologia do Desenvolvimento: o adolescente e o adulto jovem. (trad. Álvaro Cabral e Beatriz Helena de A. S. Neves). Rio de Janeiro: Campus, 1986. Volume III, 235p.

MACHADO, A. M. C. Identidade, imagem e reputação do Centro Superior de Vila Velha, na perspectiva dos alunos de graduação do curso de Ciências Econômicas. Dissertação (Mestrado em Administração) - Universidade Federal de Minas Gerais, Belo Horizonte, 2001.

MACHADO, H. V. A identidade no contexto organizacional: perspectivas de análise. Revista de Administração Contemporânea, Edição Especial, p.51-73, 2003.

; KOPITTKE, B. A identidade no contexto organizacional: perspectivas múltiplas de estudo. In: ENCONTRO DE ESTUDOS ORGANIZACIONAIS (ENEO), 2., 2002, Recife. Anais... Recife: Anpad, 2002.

MAUSS, M. Une categorie de l'esprit humain: la notion de personne celle de "moi". The Journal of the Royal Anthropological Institute of Great Britain and Ireland, v.68, p.263-281, July/Dec. 1938.

NKOMO, S. M.; COX JÚNIOR., T. Diversity identities in organizational. In: CLEGG, S. R.; HARDY, C.; NORD, W. (Ed.). Handbook of Organization Studies. London: Sage, 2001. p.338-356. Centro de Pós-Graduação e Pesquisa em Administração (Cepead), Universidade Federal de Minas Gerais (UFMG), Belo Horizonte, 2008.

PIMENTEL, T. D.; CARRIERI, A. de P.; LEITE-da-SILVA. Ambiguidades identitárias na Feira Hippie/Brasil. Revista Comportamento Organizacional e Gestão (COG), v.13, n.2, p.213-236, out. 2007.

PIMENTEL, T. D. A espacialidade na construção da identidade. Dissertação de mestrado -

REY, F. G. Pesquisa qualitativa e subjetividade: os processos de construção da informação. São Paulo: Pioneira Thomson Learning, 2005.

ROUSSEAU, J.-J. Do contrato social. São Paulo: Martin Claret, 2006.

SAINSAULIEU, R. Sociologie de l'entreprise: organisation, culture et développment. 2e éd. Paris: Presses de la Fondation Nationale des Sciences Politiques/Dalloz, 1997

SANTOS, M. A natureza do espaço: técnica e tempo. Razão e emoção. 2.ed. São Paulo: Editora Hucitec, 1997.

SOJA, E. W. Geografias pós-modernas: a reafirmação do espaço na teoria social crítica. Rio de Janeiro: Jorge Zahar Editor, 1998.

STAUB, I. Competição territorial por espaços organizacionais em processo de pós-aquisição: um estudo de empresas siderúrgicas brasileiras. Tese (Doutorado) - Centro de Pós-Graduação e Pesquisas em Administração (Cepead), Universidade Federal de Minas Gerais (UFMG), Belo Horizonte, 2004.

TAYLOR, F. W. Princípios da administração científica. São Paulo: Atlas, 1995.

TURETA, C. ALCADIPANI, R. O objeto objeto na análise organizacional: a teoria ator-rede como método de análise da participação dos não-humanos no processo organizativo. Cadernos Ebape.BR, Rio de Janeiro, v.7, n.1, mar. 2009. 
VERGARA; S, C.; VIEIRA, M. M. F. Sobre a Dimensão Tempo-Espaço na Análise Organizacional. In: Encontro Nacional de Programas de Pós-Graduação em Administração, 27., 2003, Atibaia. Anais... Atibaia: ANPAD, 2003. 1 CD-ROM.

WOOD JÚNIOR, T. Fordismo, toyotismo e volvismo: os caminhos da indústria em busca do tempo perdido. Revista de Administração de Empresas, São Paulo, v.32, p.6-18, 1992.

; CALDAS, M. P. Quem tem medo de eletrochoque? Identidade, terapias convulsivas e mudança organizacional. Revista de Administração de Empresas, São Paulo, v.35, n.5, p.13-21, 1995.

; CALDAS, M. P. Organizational identity in the third millennium: beyond central, distinctive and enduring. In: Academy of Management Annual Meeting, 2006, Atlanta. Proceeding..., Atlanta: Academy of Management Annual Meeting, 2006a..

WOOD JR., T.; CALDAS, M. P. Legacy identities during organizational change: the case of an Enron Subsidiary. In: Academy of Management Annual Meeting, 2006, Atlanta. Proceeding..., Atlanta: Academy of Management Annual Meeting, 2006b..

WOODWARD, K. Identidade e diferença: uma construção teórica e conceitual. In: SILVA, T. T. (org.) Identidade e diferença: a perspectiva dos estudos culturais. Petrópolis: Vozes, 2000. p.7-72. 